LETTERS TO THE EDITOR.

[The Editor does not hold himself responsible for opinions expressed by his correspondents. Neither can he undertake to return, or to correspond with the writers of, rejected manuscripts intended for this ar any other part of NATURE. No notice is taken of anonymous communications.]

\section{The Directorship of the Natural History Museum.}

A RETROSPECT of fifteen to itwenty years will show the effect in action of the proposed appointment of a Civil Servant to be director of the Natural History Museum.

The Science Museum adjacent had then been handed over to the direction of a Civil Service official, acting, apparently, on secret instructions that the collection of machinery and models initiated by Bennet Woodcroft was too great an expense for this country to maintain, although something less than one of our numerous Lord Chancellors; and a "ca" canny" policy was to be adopted until the director had qualified for the higher scale, when the museum was to be closed.

But the science collection was saved by a miracle from dispersal, and a competent man appointed to direct in the late Mr. Last. Too late, unfortunately, for him to secure such trophies as a broad-gauge express locomotive or the paddle-engines of the Great Eastern, to be had as a gift, and erected outside in the open if there were no funds to house them.

The historical collection was the envy of Germany, which would have bid for it, if the chance had come, to serve as the nucleus of the magnificent museum in imitation at Munich, on which no expense was spared to make it perfect and complete.

Prof. Klein was on a visit of inspection at the time to collect ideas for the projected Munich Museum, and I felt humiliated for England that he should glimpse our official mentality, and hear the low opinion held of the value of our own work, as I accompanied him round.

Quieta non movere is the motto of the old Government official. But the first act of Mr. Last's appointment was to set the collection of models at work by compressed air.

The collection grew out of the old Patent Museum, under the care of Bennet Woodcroft, encouraged by Cole, and housed in the Brompton "Boilers," Thackeray's name for the corrugated-iron sheds.

It is melancholy to reflect on the glorious chances lost by the niggardly policy lasting up to the war. The office of Master-General of the Ordnance had been re-established, entrusted with our military preparedness; and why not that of the Master-General of the Mechanicks, as Sir Samuel Morland was, for title of the director, chosen as an enthusiast, always on the look-out for additions?

But there has been no director of the Science Museum since Mr. Last. The Government official is suspicious of the competent man.

I Staple Inn, W.C.x, March 8.

\section{Absorption of Gases by Charcoal.}

OF late years much attention has been given to the remarkable power of charcoal to absorb gases of all kinds, and during the war extensive use has been made of this property in the construction of masks for removing noxious gases from the air inhaled by the wearer. As a matter of justice to the memory of a man whose interesting work in the chemistry of vegetable products is apt to be forgotten, I should like to remind readers of NATCRE that the first practical application of charcoal for such purposes was NO. 2576 , VOL. IO3] made by Dr. John Stenhouse, lecturer in chemistry at St. Bartholomew's Hospital. In 1854 Stenhouse devised a charcoal respirator consisting of a perforated zinc case filled with granular wood charcoal, and adapted to fit over the mouth and nose Respirators of this kind were in use by nurses and dressers in St. Bartholomew's, and, I believe, some other hospitals, down to the time when Lister's antiseptic system rendered such protection from the offensive emanations of sores unnecessary. When I worked in Stenhouse's private laboratory in $1862-63$ he gave me one of these respirators, and I made use of it long afterwards with great advantage wher experimenting on the gases from aqua regia and other irritating substances.

Stenhouse further succeeded in inducing the authorities of the City of London to make use of charcoal as a deodorant of the gases liable to escape from the gullies in the streets, in which application it was quite satisfactory so long as it was kept dry. The difficulty of excluding water and mud from the trays on which the charcoal was placed led, after a few years, to the abandonment of the system in the streets. The letter addressed by Stenhouse to the Lord Mayor in February, 1860 , on the subject was reviewed in the Chemical News (vol. iii., p. 78). In the same journal (vol. $x x v ., p .239$ ) there is a letter from Stenhouse dated May, 1872 , in which he refers to his respirators as then coming into use in chemical laboratories.

February 28

\section{The Profession of Chemistry.}

THE admirable article under the above title in the issue of NATURE for February 27 will be welcomed by all who cherish the belief that active development of chemical study is vital to the welfare of the State, and modestly hope that public recognition of this fact, so long deferred, may be acknowledged before it is too late. I am convinced, however, that this recognition will not be accorded until the question of nomenclature, to which you refer, has been arranged satisfactorily.

Schools and universities are not the only seats of learning. The street is one; its influence is persistent and universal, for practically all sections of the community, excepting Outer Hebridesians and Scotch crofters, come, sooner or later, under the spell of its suggestion. Yet every day, from childhood to the grave, we are told by the street that a chemist is identical with a pharmacist, and principally occupied in dispensing medicine and in the sale of toilet requisites. Is it surprising that the public is still unaware of the basic fact that the principles of chemistry lie at the foundation of our great national industries and of all the forms which life itself assumes?

In the exercise of his craft the baker practises daily some curious operations in organic chemistry which are not even yet understood by organic chemists them. selves. Supposing that some enterprising baker early in the nineteenth century had called himself a "chemist and baker," that the idea had been embraced by the whole body of bakers, and that the public, in purchasing jam-tarts or cake, had become accustomed to passing under the sign of the "Chemist and Baker," would it not be excusable if the much abused public hazily associated confectionery with argon, T.N.T., or British dyes?

The only remedy for the present situation is courteously to approach the Pharmaceutical Society and endeavour to establish a friendly arrangement, in conformity with which the members of that body, who are now variously denominated "chemist," "pharmacist," and "druggist," would content themselves 